\title{
Aynı Virüs Farklı Seyir; Monosit Kemoatraktan Protein-1 ve Sürfaktan Protein-A Düzeyinin COVID-19 Hastalarında Klinik Seyir ve Prognozla İlișkisi
}

\section{Same Virus, Different Course: The Relationship Between Monocyte Chemoattractant Protein-1 and Surfactant Protein-A Levels And Clinical Course and Prognosis of COVID-19}

\author{
Ferhan KERGET'1(ID), Bug̃ra KERGET²(ID), Sibel IBA YILMAZl'(ID), Ömer KARAȘAHIN'(ID), \\ Ahmet KIZILTUNÇ ${ }^{3}(\mathrm{IID})$, Mehtap Hülya $\operatorname{ASLAN}^{4}(\mathrm{ID})$
}

\footnotetext{
${ }^{1}$ Erzurum Bölge Eg̃itim Araștırma Hastanesi, İnfeksiyon Hastalıkları ve Klinik Mikrobiyoloji Kliniği, Erzurum, Türkiye

${ }^{2}$ Atatürk Üniversitesi Tıp Fakültesi, Göğüs Hastalıkları Anabilim Dalı, Erzurum, Türkiye

3 Atatürk Üniversitesi Tıp Fakültesi, Biyokimya Anabilim Dalı, Erzurum, Türkiye

${ }^{4}$ Erzurum Bölge Eg̃itim Araștırma Hastanesi, Mikrobiyoloji Klinig̃i, Erzurum, Türkiye
}

Makale atıfı: Kerget F, Kerget B, iba Yılmaz S, Karaşahin Ö, Kızıltunç A, Aslan MH. Aynı virüs farklı seyir; monosit kemoatraktan protein-1 ve sürfaktan protein-A düzeyinin COVID-19 hastalarında klinik seyir ve prognozla ilişkisi. FLORA 2021;26(3):410-8.

ÖZ

Giriş: Aralık 2019 tarihinde Çin'in Wuhan kentinde ortaya çıkan SARS-CoV-2'nin neden olduğu COVID-19 kısa süre içinde yüz altmış beş milyonu aşkın insanı infekte etti. COVID-19'da birçok laboratuvar parametresinin morbidite ve mortaliteyle ilişkisi tanımlanmıştır. Çalışmamızda serum monosit kemoatraktan protein-1 ve sürfaktan protein-A düzeyinin klinik seyir ve prognozla ilişkisini tespit etmeyi amaçladık.

Materyal ve Metod: 24 Mart 2020- 20 Mayıs 2020 tarihleri arasında Göğüs Hastalıkları Yoğun Bakım Kliniği ve Infeksiyon Hastalıkları kliniğinde yatmış nazofaringeal sürüntüsünden gerçek zamanlı PCR yöntemiyle COVID-19 tespit edilmiş 88 hasta ve hastanemizde rutin kontrol sonrasında gerçek zamanlı $P C R^{\prime} ı$ negatif çıkan asemptomatik 20 gönüllü sağılı personeli kontrol grubu olmak üzere 108 kişi çalışmamıza dahil edildi. Çalışmaya dahil edilen kişilerin serum monosit kemoatraktan protein-1 ve sürfaktan protein-A düzeyleri "enzyme-linked immunosorbent assay (ELISA)" yöntemiyle ölçüldü.

Bulgular: Hastaların hastaneye yatış anında bakılan monosit kemoatraktan protein-1 ve sürfaktan protein-A düzeyleri kontrol grubuna nazaran istatisksel olarak anlamlı düzeyde yüksekti $(p=0.001, p=0.001)$. Makrofaj aktivasyon sendromu gelişen hastaların hastaneye yatış sırasında ve tedavinin beşinci gününde bakılan monosit kemoatraktan protein-1 ve sürfaktan protein-A düzeyleri gelişmeyen hastalara nazaran istatistiksel olarak anlamlı düzeyde yüksek olarak gözlendi ( $p=0.001, p=0.001, p=0.05, p=0.04)$. Akut solunum sıkıntısı sendromu gelişen hastaların monosit kemoatraktan protein-1 ve sürfaktan protein-A düzeyleri hastaneye yatıs ve tedavinin beşinci gününde gelişmeyen hastalara nazaran istatistiksel olarak anlamlı düzeyde yüksekti ( $p=0.001$ hepsi için). Eksitus olan ve sağ kalan hastaların her iki parametre düzeyleri arasında da istatistiksel olarak eksitus olanlarda yüksek olmak üzere anlamlı fark gözlendi $(p=0.001, p=0.001)$.

Sonuç: COVID-19 tedavi seyrinde ve prognozda inflamatvar-antiinflamatuvar denge önemli bir yer tutmaktadır. Bu dengenin bir ucunda önemli rol oynayan monosit kemoatraktan protein-1'e karşı savunma kısmında yer alan sürfaktan protein-A klinik, seyir, prognoz ve ilerleyen dönemlerde ise tedavide önemli bir yer tutacak pnömoprotein olabilir.

Anahtar Kelimeler: COVID-19; Surfaktan protein-a; Monosit kemoatraktan protein-1 
ABSTRACT

\title{
Same Virus, Different Course: the Relationship Between Monocyte Chemoattractant Protein-1 and Surfactant Protein-A Levels and Clinical Course and Prognosis of COVID-19
}

\author{
Ferhan KERGET'1, Bug̃ra KERGET², Sibel IBA YILMAZ', Ömer KARAȘAHIN', Ahmet KIZILTUNÇ³, \\ Mehtap Hülya ASLAN ${ }^{4}$
}

\footnotetext{
${ }^{1}$ Clinic of Infectious Diseases and Clinical Microbiology, Erzurum Region Training and Research Hospital, Erzurum, Turkey

${ }^{2}$ Department of Chest Diseases, Atatürk University Faculty of Medicine, Erzurum, Turkey

${ }^{3}$ Department of Biochemistry, Atatürk University Faculty of Medicine, Erzurum, Turkey

${ }^{4}$ Clinic of Microbiology, Erzurum Region Training and Research Hospital, Erzurum, Turkey
}

Introduction: To date, over 165 million people have been infected in the COVID-19 pandemic caused by the novel coronavirus SARSCoV-2 which emerged in Wuhan, China in December 2019. This study examined the relation between serum monocyte chemoattractant protein-1 and surfactant protein-A levels and the clinical course and prognosis of COVID-19.

Materials and Methods: The study included a total of 108 subjects. Those in the patient group $(n=88)$ were diagnosed with COVID19 using real-time PCR analysis of nasopharyngeal swab samples and treated in the Pulmonary Diseases Intensive Care Unit and the Infectious Diseases Department between March 24 and May 20. The control group $(n=20)$ included asymptomatic healthcare workers whose real-time PCR results during routine COVID-19 screening in our hospital were negative.

Results: The COVID-19 patient group had significantly higher monocyte chemoattractant protein-1 and SP-A levels compared to the control group ( $p=0.001, p=0.001$ ). Patients who developed macrophage activation syndrome had significantly higher monocyte chemoattractant protein-1 and surfactant protein-A levels than those who did not both at admission $(p=0.001, p=0.001)$ and on day 5 of treatment $(p=0.05, p=0.04)$. Similarly, monocyte chemoattractant protein-1 and surfactant protein-A levels were significantly higher in patients who developed acute respiratory distress syndrome compared to those who did not at both time points ( $p=0.001$ for all). Both parameters were significantly higher in non-surviving COVID-19 patients compared to survivors ( $p=0.001$ for both).

Conclusion: Monocyte chemoattractant protein-1 and surfactant protein-A are on opposing sides of the inflammatory balance, and SP-A may be a pneumoprotein of importance in the presentation, course, prognosis, and possibly the treatment of COVID-19 in the future.

Key Words: COVID-19; Surfactant protein-A; Monocyte chemoattractant protein-1

\section{GíRiș}

Aralı 2019'da Çin'in Wuhan kentinde ortaya çkan ve kısa süre içerisinde dünyanın birçok yerine yayılan koronavirüs hastalığı (COVID-19) 165 milyonun üzerinde insanı infekte etmiștir ve sayı gün gectikçe artmaya devam etmektedir. COVID-19 çoğu infekte ettiği hastada asemptomatik ya da tat, koku kaybı, boğaz ağrısı, halsizlik, eklem ağrısı gibi hafif semptomlarla kendini göstermektedir. Ancak özellikle ileri yașta olan ve hipertansiyon, diyabet, HIV eșlik eden/AIDS uzun süre immünsüprese tedavi almak zorunda olan komorbid hastalarda ağır klinik seyir izlenebilmektedir $[1,2]$

Ağır klinik tabloların bașında hipoksik solunum yetmezliğiyle seyreden akut solunum yetmezliği sendromu (ARDS) ve makrofaj aktivasyon sendromu (MAS) gelmektedir ${ }^{[3]}$. Her iki klinik durumda da yoğun düzeyde eksprese edilen proinflamatuar sitokinler endotelyal disfonksiyona neden olarak bașta akciğer olmak üzere hayati öneme haiz organlarda hasarlanmaya neden olabilmektedirler. Yoğun bakım ihtiyacı olan hastalarda yapılan çalıșmalarda anlamlı düzeyde yüksek gözlenen ve prognozla ilișkilendirilmiș bu parametrelerin bașında IL-2, IL-6, IL-7, tümör nekroz faktör-alfa ve monosit kemoatraktan protein-1 (MCP-1) gelmektedir $[4,5]$

Doğuștan kazanılmıs immün sistemin bir üyesi olan sürfaktan protein-A (SP-A) tip 2 alveoler epitel tarafindan sentezlenen kollektin ailesinden bir proteindir. SP-A'nın yanı sıra SP-D ve mannoz-binding lectin (MBL)'de bu aileye üyedirler. $\mathrm{Bu}$ proteinler asıl alveolar makrofajlar, dentritik hücreler ve $\mathrm{T}$ hücrelerini hedeflemekte ve aglütinasyon, opsonizasyon ve modülasyonda önemli rol oynamaktadırlar. SP-A'nın akut solunum yet- 
mezliğiyle bașvuran hastalarda mekanik ventilasyon günleri ilerledikçe tedricen yükseldiği ve düșük düzeyde bașlangıc SP-A düzeyinin ağır klinik ve kötü prognozla ilișkili olduğu gözlenmiștir [6]. Ayrıca pandemik influenza-A döneminde SP-A'da gözlenen tek nükleotid polimorfizmi ile kötü prognoz ve klinik seyir ilișkili olarak değerlendirilmiștir. Akciğer malignitesi gibi non-infeksiyöz akciğer hastalıklarında ise SP-A monositlerin M1 monosit olarak farklılașmasına ve naturel killer hücrelerden perforin-1 ve granyzme-B sentezini induikleyerek anti-tümoral etki gösterilmesini sağlamaktadır ${ }^{[7]}$.

Calısmamızda daha önceden COVID-19 prognozunda önemli rol oynayan MCP-1 düzeyi ile akut solunum yetmezliŏi bașta olmak üzere inflamatuvar ve non-inflamatuvar akciğer hastalıklarında rol oynayan SP-A'nın klinik seyir ve prognozla ilișkisini araștırmayı hedefledik.

\section{MATERYAL ve METOD}

Calıșmamızda hastanemiz acil servisine yeni bașlayan ates, öksürük, nefes darlığı, halsizlik, ani bașlayan tat ve koku duyusunda azalma sikayetleri bașta olmak üzere son 14 gün içerisinde yurt dișı ziyaretinden dönen, suipheli COVID-19 hastası ile temas etmis olan hastalar dahil edildi. Laboratuvar araștırmasına bașlamadan önce etik kurul onayı alınmıștır (BEAH KAEK 2019/10-104).

COVID-19 açısından yüksek riskli hastaların posterior-anterior akciğer grafileri cekildi, șüpheli lezyonların varlığı durumunda yüksek rezolüsyonlu toraks bilgisayarlı tomografi ile bulgular detaylı olarak değerlendirildi. Hastalardan nazaofaringeal sürüntü alınarak gerçek zamanlı PCR metoduyla COVID-19 tanisı konuldu (SARS-CoV-2 RT-qPCR Tespit Kiti, BioRad CFX96 Touch Real Time PCR, CA, ABD). Hastanemizde ilk pozitif vaka 24 Mart 2020 tarihinde saptand. Bu süreden itibaren 25 Mayıs 2020'ye kadar Göğuis Hastalıkları ve İnfeksiyon Hastalıkları Kliniği tarafından takip edilen 88 hasta ve hastanemizde rutin COVID-19 taraması sırasında gerçek zamanlı PCR sonucu negatif olarak gelen semptomatik olmayan 20 gönülliu sağlık calıșanı olmak üzere toplam 108 kiși çalıșmamıza dahil edildi. Hastaların kliniğe yatıs verildikten sonra hematolojik parametreleri, karaciğer ve böbrek fonksiyon testlerini içerecek sekilde biyokimyasal parametreleri, pihtılașma paremetreleri, ferritin, D-Dimer, troponin-I, C-reaktif protein (CRP), ve arteryal kan gazı parametrelerine bakıldı. Hastaların mevcut laboratuvar parametreleri günlük olarak tekrarland.

\section{Tanımlar ve Tedavi}

Hastalarda aksiller olarak ölçuilen ve $37.3^{\circ} \mathrm{C}$ üstünde olan sıcaklık ates olarak tanımlandı. Bakteriyemi veya pnömoni semptom ve bulgularıla seyreden alt solunum yollarından endotrakeal aspirat ya da balgamla yeni bir patojen ile pozitif kültuir örneğinin gösterilmesi sekonder bakteriyel infeksiyon olarak tanımlandı. Ventilatör ile ilișkili veya hastane kaynaklı pnömoni tanısı konulan hastalara mevcut kılavuzlar doğrultusunda tedavi planlandı. Akut solunum yetmezliği tanısı ve derecelendirmesi Berlin 2015 tanı kriterlerine göre konuldu. Hastaların günlük bakılan kardiyak spesifik troponin düzeyinin normalin üstünde gözlenmesi durumunda ekokardiyografi ile yeni gelișmiș olabilecek kardiyak patolojiler açısından değerlendirildi. Koagülapati olarak protrombin zamanında normalin üç saniye üstü, parsiyel tromboplastin düzeyinde ise normalin beș saniye üstü koagülopati olarak tanımland. Hastaların ağırlıklarına göre tedavi stratejisi Türkiye Cumhuriyeti Sağlık Bakanlığı COVID-19 erișkin tanı ve tedavi rehberine göre yapıldı. Tedaviye rağmen devam eden direncli ates, devaml yüksek seyreden ya da artmaya devam eden CRP ve ferritin değerleri, D-dimer yüksekliği, lenfopeni ve trombositopeni seklinde sitopeniler, karaciğer fonksiyon testlerinde bozulma, hipofibrinojenemi veya trigliserid değerlerinde yükselme gibi bulgularının varlığı durumunda hastalar MAS açısından takibe alındı. Bu parametrelerde günlük bakılan ardıșık ölçümlerde yükselme olması ve bu durumun sekonder bakteriyel infeksiyonlar ile açklanamaması durumunda hastalara MAS'a yönelik kontrendike durum yok ise $400 \mathrm{mg}$ tosilizumab uygulaması yapildı. Tosilizumab 24 saat sonra uygun klinik ve laboratuvar yanıt alınan hastalarda tekrarlanmadi. Ancak uygun klinik ve laboratuvar yanit alınmaması durumunda aynı dozda tekrarland.

\section{Biyokimyasal Parametrelerin Ölçiimii}

On bes dakikalık yarı-sırtüstü dinlenme sonrasında, pıhtılașmayı önlemek için antekübital bir venden etilendiamintetraasetik asit (EDTA) içeren tüplere kan örnekleri alınd. Troponin I konsantrasyonları, bir Immulite 2500 (Siemens Medical 
Solutions, Erlangen, Almanya) kullanilarak kemiluiminesan immünoassay ile ölçüldü. MCP-1 ve SPA, enzime bağlı immünosorbent analizi ile ölçüldü (Elabscience insan ELISA kiti, İngiltere).

\section{İstatistiksel Analiz}

İstatistiksel analizler SPSS for Windows (sürüm 24.0; SPSS Inc., Chicago, Ill., ABD) ile yapildı. Gruplar arası parametrik verilerin karșlaștırılmasında Pearson ki-kare testi kullanıldı; normal dağılmayan sayısal verilerin gruplar arası karșılaștırmalarında Mann-Whitney $U$ testi kullanıldı. Grupların demografik verileri ve laboratuvar parametreleri bağımsız örnekler $t$ testi kullanılarak değerlendirildi. Grupların takiplerindeki parametrelerinin karșlaștırılmasında ise Wilcoxon analizi yapıld. MCP-1, SP-A seviyeleriyle CRP, ferritin, D-Dimer, lenfosit, nötrofil/lenfosit oranı, troponin-I ve $\mathrm{PaO}_{2} / \mathrm{FiO}_{2}$ arasındaki korelasyonları tespit etmek için Pearson korelasyon analizi kullanıld. 0.05'ten küçük bir p değeri istatistiksel olarak anlamlı kabul edildi.

\section{BULGULAR}

Calıșmamıza dahil edilen hastaların 47 (\%53.4)'si kadındı. Kontrol grubundaki hastaların ise 12 (\%60)'si kadındı. Hastaların yas ortalaması

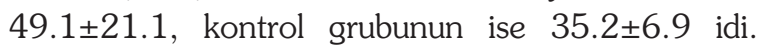
Hasta gruplar arasında cinsiyet ile yas arasında istatistiksel olarak anlamlı fark gözlenmedi ( $p=$ 0.196). COVID-19 hastalarınında gözlenen komorbid durumlar Tablo 1'de gösterilmiștir.

\begin{tabular}{|c|c|c|c|}
\hline & $\begin{array}{l}\text { Hastaneye yatış }(\mathrm{n}=88) \\
(\text { Ortalama } \pm \text { SD) }\end{array}$ & $\begin{array}{l}\text { Tedavinin 5. günü }(n=88) \\
\text { (Ortalama } \pm \text { SD) }\end{array}$ & $p$ \\
\hline WBC $(/ \mu l)$ & $7120.4 \pm 3984.6$ & $7045.2 \pm 2289.1$ & 0.71 \\
\hline Lenfosit $(/ \mu \mathrm{l})$ & $1413.1 \pm 789.2$ & $1941.1 \pm 924.1$ & 0.001 \\
\hline Nötrofil $(/ \mu \mathrm{l})$ & $4875.1 \pm 3116.4$ & $4428.2 \pm 3145.4$ & 0.25 \\
\hline NLO & $6.1 \pm 8.1$ & $4.4 \pm 7.3$ & 0.02 \\
\hline AST (U/L) & $33.8 \pm 22.1$ & $32.4 \pm 30.4$ & 0.21 \\
\hline ALT (U/L) & $31.4 \pm 26.3$ & $30.2 \pm 25.6$ & 0.3 \\
\hline LDH (U/L) & $321.6 \pm 146.7$ & $315.2 \pm 190.1$ & 0.28 \\
\hline GGT (U/L) & $38.8 \pm 35.3$ & $42.7 \pm 36.8$ & 0.33 \\
\hline $\operatorname{ALP}(U / L)$ & $70.2 \pm 40.1$ & $68.6 \pm 30.1$ & 0.25 \\
\hline Sodyum (mmol/L) & $139.2 \pm 4.1$ & $140.3 \pm 4.1$ & 0.04 \\
\hline Potasyum (mmol/L) & $4.2 \pm 0.4$ & $4.5 \pm 0.6$ & 0.001 \\
\hline Kreatin $(\mathrm{mg} / \mathrm{dL})$ & $1.1 \pm 0.9$ & $1.1 \pm 0.9$ & 0.319 \\
\hline Protrombin zamanı (s) & $16 \pm 7.1$ & $13.7 \pm 6$ & 0.001 \\
\hline CRP (mg/dL) & $78.2 \pm 90.1$ & $24.3 \pm 26.2$ & 0.001 \\
\hline Troponin-I (ng/dl) & $70.2 \pm 216.2$ & $152.2 \pm 1211.1$ & 0.001 \\
\hline $\mathrm{PaO}_{2} / \mathrm{FiO}_{2}$ & $286.1 \pm 70.1$ & $333.1 \pm 50.8$ & 0.001 \\
\hline D-Dimer (ng/ml) & $1253.4 \pm 1918.2$ & $641.1 \pm 876.1$ & 0.001 \\
\hline MCP-1 (pg/ml) & $116.1 \pm 171.2$ & $76.4 \pm 62.3$ & 0.001 \\
\hline \multirow[t]{2}{*}{ SP-A (pg/ml) } & $387.4 \pm 366.9$ & $250.4 \pm 110.8$ & 0.001 \\
\hline & MCP-1 (pg/ml) & SP-A (pg/ml) & \\
\hline Kontrol $(n=20)$ & $50.3 \pm 32.1$ & $220.8 \pm 128.7$ & \\
\hline$p^{*}$ & $0.001 / 0.03$ & $0.001 / 0.4$ & \\
\hline
\end{tabular}


Hastaların laboratuvar parametrelerinin hastaneye yatıs ve tedavinin beșinci gününde karșlaștırmalı analiziyle kontrol grubu hastaların MCP-1 ve SP-A düzeyleri Tablo 2'de gösterilmiștir. Hastaların hastaneye yatıs ve tedavinin beșinci gününde bakılan MCP-1 ve SP-A düzeyleri arasında yatıs anında daha fazla olmak üzere istatistiksel olarak anlamlı sonuc gözlendi ( $p=0.001, p=0.001)$. Hastaların hastaneye yatıs anında bakılan MCP1 ve SP-A düzeyleri kontrol grubuna nazaran istatistiksel olarak anlaml düzeyde yüksek iken $(p=0.001, p=0.001)$, tedavinin besinci gününde bakılan değerleri yine kontrol grubuna nazaran yüksek olmakla birlikte sadece MCP-1 düzeyinde anlamlı fark gözlendi $(p=0.03, p=0.4)$. MAS gelișen $(n=20)$ ve gelișmeyen $(n=68)$ hastaların laboratuvar parametrelerinin hastaneye yatıs ve tedavinin beșinci gününde karșılaștırmalı analizi Tablo 3'te gösterilmiștir. MAS gelișen hastaların hastaneye yatıs sırasında ve tedavinin beșinci gününde bakılan MCP-1 ve SP-A düzeyleri gelișmeyen hastalara nazaran istatistiksel olarak anlaml düzeyde yüksek olarak gözlendi $(p=0.001, p=$ $0.001, p=0.05, p=0.04)$. ARDS gelișen ( $\mathrm{n}$ : 35) ve gelismeyen ( $\mathrm{n}=53$ ) hastaların laboratuvar parametrelerinin hastaneye yatıs ve tedavinin beșincigününde karșılaștırmalı analizi Tablo 4'te gösterilmiștir. ARDS gelișen hastaların MCP-1 ve SP-A düzeyleri hastaneye yatıs ve tedavinin 5 . gününde gelișmeyen hastalara nazaran istatistiksel olarak anlaml düzeyde yüksekti $(p=0.001$ hepsi için). Hastaların yedisinde eksitus oldu. Eksitus

Tablo 2. Makrofaj aktivasyon sendromu (MAS) geliştiren ve geliştirmeyen COVID-19 hastaları arasında hastaneye yatış ve 5. günde laboratuvar parametrelerinin karşılaştırılması

\begin{tabular}{|c|c|c|c|c|c|}
\hline & \multicolumn{2}{|c|}{ MAS gelişenler $(n=20)$} & \multicolumn{2}{|c|}{ MAS gelişmeyenler $(n=68)$} & \multirow[b]{2}{*}{$\mathbf{p}$} \\
\hline & Hastaneye yatış & $\begin{array}{l}\text { Tedavinin } \\
5 . \text { günü }\end{array}$ & Hastaneye yatış & $\begin{array}{l}\text { Tedavinin } \\
\text { 5. günü }\end{array}$ & \\
\hline WBC $(/ \mu \mathrm{l})$ & $8937.1 \pm 7315.4$ & $8874.8 \pm 5796.1$ & $6801.2 \pm 3111.2$ & $6610.2 \pm 1999.8$ & $0.17 / 0.01$ \\
\hline Lenfosit $(/ \mu \mathrm{l})$ & $715.2 \pm 521.8$ & $1130.2 \pm 720.8$ & $1800.1 \pm 901.1$ & $2123.1 \pm 910.2$ & $0.001 / 0.001$ \\
\hline Nötrofil $(/ \mu \mathrm{l})$ & $7533.1 \pm 6500.6$ & $7299.8 \pm 5584.5$ & $4298.4 \pm 1789.2$ & $3876.2 \pm 1796.2$ & $0.04 / 0.001$ \\
\hline NLO & $14.4 \pm 16.2$ & $11.7 \pm 17.2$ & $3.2 \pm 2.5$ & $2.3 \pm 2.1$ & $0.006 / 0.001$ \\
\hline AST (U/L) & $44.2 \pm 20.1$ & $60.2 \pm 64.1$ & $31.2 \pm 25.4$ & $24.8 \pm 8.6$ & $0.01 / 0.001$ \\
\hline $\operatorname{ALT}(\mathrm{U} / \mathrm{L})$ & $35.9 \pm 27.1$ & $42.1 \pm 35.6$ & $28.1 \pm 23.8$ & $27.4 \pm 20.1$ & $0.15 / 0.01$ \\
\hline LDH (U/L) & $451.3 \pm 320.1$ & $604.2 \pm 300.2$ & $281.3 \pm 124.6$ & $250.2 \pm 89.2$ & $0.001 / 0.001$ \\
\hline GGT (U/L) & $56.9 \pm 48.2$ & $77.4 \pm 55.6$ & $30.1 \pm 25.4$ & $36.6 \pm 29.1$ & $0.02 / 0.001$ \\
\hline $\operatorname{ALP}(\mathrm{U} / \mathrm{L})$ & $79.6 \pm 36.8$ & $69.8 \pm 32.4$ & $80.2 \pm 45.2$ & $72.2 \pm 39.4$ & $0.58 / 0.6$ \\
\hline Sodyum (mmol/L) & $138.2 \pm 7.2$ & $146.4 \pm 8.2$ & $139.4 \pm 4.2$ & $138.4 \pm 4.1$ & $0.5 / 0.001$ \\
\hline Potasyum (mmol/L) & $4.2 \pm 0.4$ & $4.5 \pm 0.4$ & $4.2 \pm 0.5$ & $4.4 \pm 0.6$ & $0.7 / 0.52$ \\
\hline Kreatin (mg/dl) & $1.9 \pm 1.8$ & $2.2 \pm 1.9$ & $0.8 \pm 0.6$ & $0.8 \pm 0.3$ & $0.02 / 0.001$ \\
\hline Protrombin zamanı (s) & $21.1 \pm 13.1$ & $19.5 \pm 9.6$ & $13.8 \pm 3.6$ & $13.4 \pm 1.7$ & $0.01 / 0.001$ \\
\hline CRP $(\mathrm{mg} / \mathrm{dl})$ & $180.2 \pm 80.2$ & $49.1 \pm 30.2$ & $25.6 \pm 33.6$ & $10.3 \pm 17.2$ & $0.001 / 0.001$ \\
\hline Troponin-I (ng/dl) & $255.2 \pm 623.4$ & $681.2 \pm 2620.8$ & $7.7 \pm 16.4$ & $4.1 \pm 7.7$ & $0.001 / 0.001$ \\
\hline $\mathrm{PaO}_{2} / \mathrm{FiO}_{2}$ & $210.2 \pm 70.9$ & $294.9 \pm 45.2$ & $320.2 \pm 50.4$ & $335.8 \pm 50.2$ & $0.001 / 0.002$ \\
\hline D-Dimer (ng/ml) & $2611.1 \pm 3220.4$ & $1333.2 \pm 1453.4$ & $801.4 \pm 900.1$ & $481.6 \pm 621.5$ & $0.001 / 0.001$ \\
\hline Ferritin $(\mathrm{ng} / \mathrm{ml})$ & $1209.1 \pm 1601.8$ & $510.1 \pm 90.4$ & $350.2 \pm 145.8$ & $139.2 \pm 80.1$ & $0.001 / 0.001$ \\
\hline MCP-1 (pg/ml) & $353.1 \pm 223.3$ & $190.8 \pm 170.9$ & $49.9 \pm 65.5$ & $25.1 \pm 20.9$ & $0.001 / 0.001$ \\
\hline $\mathrm{SP}-\mathrm{A}(\mathrm{pg} / \mathrm{ml})$ & $534.7 \pm 388.7$ & $245.4 \pm 120.1$ & $346.3 \pm 345.6$ & $180.6 \pm 110.8$ & $0.05 / 0.04$ \\
\hline
\end{tabular}

MAS: Makrofaj aktivasyon sendromu, WBC: Beyaz küre, NLR: Nötrofil/lenfosit ratio, AST: Aspartat aminotransferaz, ALT: Alanin aminotransferaz, LDH: Laktat dehidrojenaz, GGT: Gama glutamil transferaz, ALP: Alkalin fosfataz, MCP-1: Monosit kemoatraktan protein-1, SP-A: Sürfaktan Protein-Al

p: Gruplar arasında hastaneye yatış ve tedavinin 5. gününde parametrelerin karşılaştırılması. 
Tablo 3. Akut solunum sıkıntısı sendromu (ARDS) gelişen ve gelişmeyen COVID-19 hastaları arasında hastaneye yatış ve 5 . günde laboratuvar parametrelerinin karşılaştırılması

\begin{tabular}{|c|c|c|c|c|c|}
\hline & \multicolumn{2}{|c|}{ ARDS gelişenler $(n=35)$} & \multicolumn{2}{|c|}{ ARDS gelişmeyenler $(n=53)$} & \multirow[b]{2}{*}{$\mathbf{p}$} \\
\hline & Hastaneye yatış & $\begin{array}{c}\text { Tedavinin } \\
\text { 5. günü }\end{array}$ & Hastaneye yatış & $\begin{array}{c}\text { Tedavinin } \\
5 . \text { günü } \\
\end{array}$ & \\
\hline WBC $(/ \mu \mathrm{l})$ & $7980.2 \pm 6004.2$ & $8083.2 \pm 4366.4$ & $6453.4 \pm 2014.2$ & $6244.8 \pm 2055.5$ & $0.09 / 0.03$ \\
\hline Lenfosit $(/ \mu \mathrm{l})$ & $881.9 \pm 501.4$ & $1266.4 \pm 681.8$ & $1999.9 \pm 910.2$ & $2200.4 \pm 820.2$ & $0.001 / 0.001$ \\
\hline Nötrofil $(/ \mu \mathrm{l})$ & $6500.2 \pm 5200.1$ & $6350.2 \pm 4236.8$ & $3998.6 \pm 1461.2$ & $3528.4 \pm 1568.4$ & $0.001 / 0.001$ \\
\hline NLO & $10.1 \pm 11.8$ & $9.1 \pm 11.4$ & $2.4 \pm 1.2$ & $1.9 \pm 0.8$ & $0.001 / 0.001$ \\
\hline AST (U/L) & $43.5 \pm 26.2$ & $45.3 \pm 51.4$ & $27.1 \pm 15.1$ & $24.1 \pm 11.1$ & $0.001 / 0.002$ \\
\hline $\operatorname{ALT}(\mathrm{U} / \mathrm{L})$ & $33.8 \pm 29.7$ & $35.1 \pm 28.1$ & $28.1 \pm 21.1$ & $27.8 \pm 19.9$ & $0.41 / 0.22$ \\
\hline $\mathrm{LDH}(\mathrm{U} / \mathrm{L})$ & $428.9 \pm 191.2$ & $455.2 \pm 261.2$ & $238.1 \pm 66.8$ & $222.2 \pm 70.8$ & $0.001 / 0.001$ \\
\hline GGT (U/L) & $60.8 \pm 38.2$ & $55.2 \pm 47.2$ & $28.8 \pm 21.1$ & $30.2 \pm 26.2$ & $0.001 / 0.02$ \\
\hline $\operatorname{ALP}(U / L)$ & $88.8 \pm 50.4$ & $64.2 \pm 30.6$ & $69.9 \pm 28.8$ & $70.4 \pm 28.2$ & $0.07 / 0.61$ \\
\hline Sodyum (mmol/L) & $137.2 \pm 5$ & $142.4 \pm 6.4$ & $138.6 \pm 3.1$ & $139.4 \pm 2.5$ & $0.004 / 0.07$ \\
\hline Potasyum (mmol/L) & $4.1 \pm 0.5$ & $4.4 \pm 0.6$ & $4.3 \pm 0.4$ & $4.4 \pm 0.4$ & $0.2 / 0.3$ \\
\hline Kreatin (mg/dl) & $1.4 \pm 1.4$ & $1.6 \pm 1.5$ & $0.8 \pm 0.4$ & $0.8 \pm 0.3$ & $0.03 / 0.001$ \\
\hline Protrombin zamanı (s) & $20.1 \pm 8.6$ & $18.1 \pm 8.2$ & $13.4 \pm 2.6$ & $13.7 \pm 1.8$ & $0.001 / 0.001$ \\
\hline CRP (mg/dl) & $145.5 \pm 98.8$ & $38.2 \pm 30.6$ & $15.8 \pm 18.4$ & $5.6 \pm 15.4$ & $0.001 / 0.001$ \\
\hline Troponin-I (ng/dl) & $170.2 \pm 513.2$ & $391.3 \pm 1901.5$ & $6.4 \pm 9.6$ & $1.9 \pm 1.6$ & $0.001 / 0.001$ \\
\hline $\mathrm{PaO}_{2} / \mathrm{FiO}_{2}$ & $224.6 \pm 60.2$ & $299.9 \pm 52.4$ & $339.8 \pm 32.6$ & $343.5 \pm 49.9$ & $0.001 / 0.001$ \\
\hline D-Dimer (ng/ml) & $2200.9 \pm 2730.8$ & $1270.4 \pm 1354.4$ & $545.4 \pm 250.4$ & $345.6 \pm 140.6$ & $0.001 / 0.001$ \\
\hline Ferritin $(\mathrm{ng} / \mathrm{ml})$ & $768.4 \pm 1256.8$ & $411.8 \pm 360.4$ & $338.4 \pm 138.2$ & $176.1 \pm 33.8$ & $0.01 / 0.01$ \\
\hline MCP-1 (pg/ml) & $246.3 \pm 211.5$ & $160.2 \pm 134.8$ & $30.1 \pm 28.7$ & $22.8 \pm 18.6$ & $0.001 / 0.001$ \\
\hline SP-A (pg/ml) & $517.3 \pm 414.3$ & $259.8 \pm 200.7$ & $301.6 \pm 306.9$ & $100.5 \pm 88.4$ & $0.001 / 0.001$ \\
\hline
\end{tabular}

olan hastaların MCP-1 ve SP-A düzeyleri 459.4 $\pm 180.1 \mathrm{pg} / \mathrm{ml}$ ve $905.8 \pm 467.5 \mathrm{pg} / \mathrm{ml}$ iken sağ kalan hastalarda $90.7 \pm 142.7 \mathrm{pg} / \mathrm{ml}$ ve $349.1 \pm 333.4 \mathrm{ng} / \mathrm{ml}$ idi. Eksitus olan ve sağ kalan hastaların her iki parametre düzeyleri arasinda da istatistiksel olarak anlamlı fark gözlendi $(p=0.001, p=0.001)$.

MCP-1 düzeyi ile hastaların hastaneye gelis laboratuvar parametreleri arasinda yapilan korelasyon analizinde lenfosit düzeyi, $\mathrm{PaO}_{2} / \mathrm{FiO}_{2}$ düzeyi ile ters yönde korelasyon $(r=-0.42, p=0.01, r=$ $-0.65, p=0.01$ ) (Sekil 1), nötrofil lenfosit oranı, laktat dehidrojenaz düzeyi, kreatin, protrombin zamanı, CRP, troponin-I, D-dimer ve SP-A dü- zeyleri arasında ise pozitif yönde korelasyon gözlendi $(r=0.4, p=0.01 ; r=0.56, p=0.01 ; r=$ $0.32, p=0.01 ; r=0.52, p=0.01 ; r=0.74, p=$ $0.05, r=0.314, p=0.01, r=0.42, p=0.01$; $\mathrm{r}=0.352, \mathrm{p}=0.01$ ) (Sekil 1).

SP-A düzeyi ile hastaların hastaneye gelis laboratuvar parametreleri arasında yapilan korelasyon analizinde ise lenfosit ve $\mathrm{PaO}_{2} / \mathrm{FiO}_{2}$ oranı ile ters korelasyon $(\mathrm{r}=-0.248, \mathrm{p}=0.01 ; \mathrm{r}=-0.371, \mathrm{p}=$ 0.01), CRP, LDH, protrombin zamanı ve D-dimer düzeyiyle ise pozitif yönde korelasyon gözlendi $(r=$ $0.331, p=0.01 ; \mathrm{r}=0.361, \mathrm{p}=0.01 ; \mathrm{r}=0.464$, $\mathrm{p}=0.01 ; \mathrm{r}=0.32, \mathrm{p}=0.01$ ) (Sekil 1). 


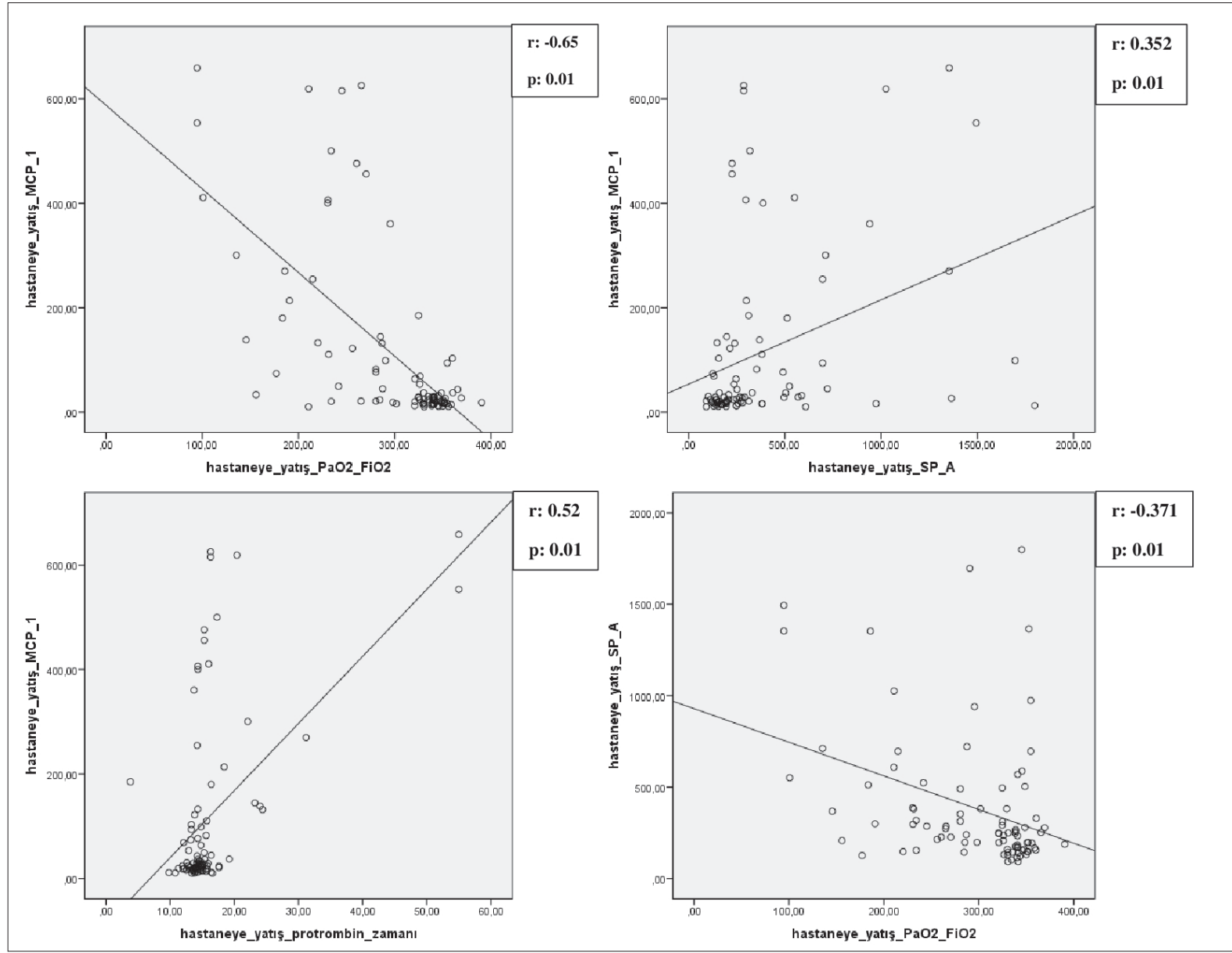

Şekil 1. Hastaneye yatış MCP-1, SP-A düzeyinin hastaneye yatış protrombin zamanı ve $\mathrm{PaO}_{2} / \mathrm{FiO}_{2}$ ile korelasyon analizi.

\section{TARTIȘMA}

2019 yilının Aralık ayında Cin'in Wuhan kentinde yeni bir virüs keșfedildi ve bu virüsü Uluslararası Virüs Taksonomisi Komitesi, Siddetli Akut Solunum Sendromu Coronavirus 2 (SARS-CoV-2) ve Dünya Sağllk Örgütü (WHO) ile ilișkili olarak COVID-19 olarak adlandırmıștır ${ }^{[8]}$. Simdiye kadar COVID-19 nedeniyle infekte insan sayisinın 165 milyonun üzerinde olduğu söylenmektedir.

Calısmamizda MCP-1 ve SP-A düzeylerinin COVID-19 nedeniyle takip edilen hastalarda kontrol grubuna göre yüksek seyrettiğini ve takiplerinde gerilediğini gözlemledik. Yüksek düzeyde tespit edilen MCP-1 ve SP-A düzeyi ile ARDS ve MAS gelișimi arasında yakın ilișki olduğunu tespit ettik. Eksitus olan hastalarda yașayan hastalara nazaran daha yüksek düzeyde $\mathrm{MCP}-1$ ve $\mathrm{SP}-\mathrm{A}$ düzeyi olduğunu gözlemledik. COVID-19 klinik seyir ve takibinde önemli yer tutan MCP-1, CRP, LDH ve D-dimer ile SP-A düzeyi arasında pozitif yönlü, lenfosit ve $\mathrm{PaO}_{2} / \mathrm{FiO}_{2}$ oranı ile ise negative yönlü korelasyon gözlendi.

SARS-CoV veya MERS-CoV için alıṣlmadık derecede ağır seyreden klinik tablonun patofizyolojisi tam olarak anlașlamamıștır. İlk çalıșmalar, serumdaki proinflamatuar sitokinlerin (örneğin; IL-1B, IL-6, IL-12, IFN- $\gamma$, ve MCP-1) artmis miktarlarının SARS hastalarında pulmoner inflamasyon ve yaygın akciğer hasarıyla ilișkili olduğunu göstermistir ${ }^{[3,5,9]}$. MERS-CoV hastalarında yapılan çalıșmalarda virüsün IFN- $\gamma$, TNF- $\alpha$, IL-15 ve IL-17 gibi proinflamatuar sitokin düzeylerini de indüklediği gözlenmiștir ${ }^{[10,11]}$. COVID-19 ile yapilan calısmalar da MERS-CoV ile uyumlu olarak IL-1B, IFN- $\gamma$ ve MCP-1 düzeylerinde anlaml derecede yükselme olduğu gözlenmiștir. Ayrıca 
yoğun bakım ihtiyacı olan hastalarda olmayanlara nazaran MCP-1 ve TNF- $\alpha$ düzeyinin daha yüksek olduğu tespit edilmiștir ${ }^{[12,13]}$. Biz de çalıșmamızda önceki çalıșmalarla uyumlu olarak ARDS nedeniyle yoğun bakım ihtiyacı gözlemlenen hastalarda MCP-1 düzeyini anlamlı derecede yüksek olarak tespit ettik ${ }^{[14]}$. COVID-19'da morbidite ve mortalitenin en önemli nedenlerinden birini de sitokin fırtınası sendromu olușturmaktadır. Sitokin firtınası sonrasında bașta TNF- $\alpha$, IL-1, IL-2, IL-6, MCP-1, nitrik oksit olmak üzere bir cok proinflamatuar sitokin açığa cıkar. Bu sitokinler vasküler permabilitenin artıșına neden olarak doku perfüzyonunda bozulmanın yanı sıra endotelyal hasarlama ve mikrotombüs olușumuna da neden olabilmektedirler ${ }^{[15,16]}$. Vasküler permeabilitedeki bu artıs akciğer dokusunda ve interstisyel alanda sivı birikimine bunun sonucunda da akut solunum yetmezliği tablosunun olușmasına neden olmaktadır ${ }^{[17]}$. Bizim calıșmamızda da özellikle MAS gelișen hastalarda gelișmeyenlere nazaran daha yüksek duizeyde MCP-1 düzeyi saptadık.

Akut solunum yetmezliğinde hipoksik solunum yetmezliği tablosunun olușumun da ve ağırlașmasinda endotelyal hasar önemli rol oynar. Alveollerde gözlenen tip 2 epitel hasarı sürfaktan üretiminde rol oynayan bu hücrelerde üretimin bozulmasına ve mikroatelektazik alanların gelișmesine neden olur. Sürfaktan alveol duvarında ekspansasyonu kolaylaștırdığı gibi doğustan immun savunmada önemli rol oynar ${ }^{[18]}$. SP-A doğuștan gelen immün savunmada da rol oynayan kollektin ailesine üye bir proteindir. $\mathrm{Bu}$ ailede SP-D ve MBL'de bulunmaktadır ${ }^{[19,20]}$. Bu proteinler, hasarl hücrelere alveoler makrofaj, dentritik hücreler ve $\mathrm{T}$ lenfositlerin aglütinasyon, opsonizasyon ve modülasyonunu sağlayarak mikrobiyal klirenste rol oynamaktadır. SP-A duizeyi ile akut solunum yetmezliği gelișen hastalarda yapılan calıșmalarda SP-A düzeyinin mekanik ventilatör süresiyle uyumlu olarak yükseldiği ve ARDS tablosunun bașında gözlenen yüksek SP-A düzeyinin kötü prognoz ve kötü klinik seyir ile ilișkili olduğu tespit edilmiș$\operatorname{tir}^{[18,21]}$.

SARS-CoV-2 (COVID-19) hastalarının takiplerinin değerlendirildiği çalıșmamızda klinik seyir ve prognozla ilișkilendirilmiș olan protrombin zamanı,
CRP, troponin-I, MCP-1 ve D-dimer duizeylerinin hastalığın başlangıcında yüksek olup tedaviyle birlikte gerilediğini gözlemledik. COVID-19 hastalarında mortalitenin en önemli nedenleri arasında yer alan ARDS'nin gözlenen hastalarda daha önceden yapilan calıșmalarla uyumlu olarak hastanaye yatıșında bakılan SP-A düzeyinin yüksek seyrettiğini ve tedaviyle birlikte gerilediğini tespit ettik. Bu durum ön planda antiinflamatuvar etkinliği vurgulanan SP-A'nın tedaviyle birlikte azalıș gösteren enflamatuar yanita karșı daha az rol oynadığı yönünde değerlendirilebilir. MAS patogenezinde MCP-1'in önemli rol oynadığı önceki calıșmalarda gösterilmiștir. Calıșmamızda, COVID-19, MAS ilișkisinde MCP-1 yanı sıra SP-A duizeyleri ilk kez calıșılmıștır. SP-A düzeyleri MAS gelișenlerde gelismeyenlere göre anlamlı olarak yüksek bulunmustur. $\mathrm{Bu}$ durum da ARDS patogenezi ile uyumlu olarak inflamatuvar yanitın bu hastalarda daha yüksek olması ve bu durumu dengelemeye çalıșan SP-A düzeyinin arttığı yönünde yorumlanabilir. Eksitus olan hastalarda sağ kalanlara göre cok daha yüksek tespit edilen MCP-1 ve SP-A düzeyi bu iki biyolojik göstergenin mortalite için önemli belirteç olabileceği yönünde değerlendirilebilir.

Calıșmamızda eksitus olan hasta sayısının az olması MCP-1 ve SP-A'nın mortalite ile ilișkisinin belirlenmesinde en önemli kısıtlılığımız olmuștur. Ancak calıșmamızın belirlenen tarihler arasında bölgemizdeki iki pandemi hastanesinde gözlenen tüm eksitusları kapsamıs olması mortal olguların seyrinin değerlendirilmesinde kullanılabilecek en önemli kaynak özelliği tașımaktadır.

Sonuc olarak COVID-19 hastalarında bașlangiçta tespit edilen yüksek MCP-1 ve SP-A düzeyi ARDS, MAS ve eksitus gelișimi açısından erken dönemde yakın takip ve tedavi planlanması açsından yol gösterici parametreler olabilirler. Ayrica SP-A ilerleyen dönemlerde yapilacak calıșmalarda COVID-19 hastaları için tedavi planlanmasında kullanılabilecek bir pnömoprotein olabilir.

\section{ETIK KURUL ONAYI}

$\mathrm{Bu}$ çalıșma, Sağlık Bilimleri Üniversitesi Erzurum Bölge Eğitim ve Araștırma Hastanesi Klinik Araștırmalar Etik Kurulu onayı ile gerçekleștirilmiștir. 


\section{ÇIKAR ÇATIŞMASI}

Yazarlar bu makale ile ilgili herhangi bir c1kar çatıșması bildirmemișlerdir.

\section{YAZAR KATKISI}

Anafikir/Planlama: F.K, B.K

Analiz/Yorum: B.K, A.K

Veri Sağlama: S.I.Y, Ö.K, M.H.A

Yazım: F.K

Gözden Geçirme ve Düzeltme: B.K, A.K

Onaylama: A.K, B.K

\section{KAYNAKLAR}

1. World Health Organization (WHO). Available from: https:// apps.who.int/iris/bitstream/handle/10665/331784/nCoVsitrep15Apr2020-eng.pdf Accessed date: 15 april 2020

2. Bai $Y$, Yao L, Wei T, Tian F, Jin D-Y, Chen L, et al. Presumed asymptomatic carrier transmission of COVID-19. Jama 2020;323:1406-7.

3. Mehta P, McAuley DF, Brown M, Sanchez E, Tattersall RS, Manson JJ, et al. COVID-19: consider cytokine storm syndromes and immunosuppression. Lancet 2020;395:1033.

4. Rothan HA, Byrareddy SN. The epidemiology and pathogenesis of coronavirus disease (COVID-19) outbreak. J Autoimmune 2020;109:1-4.

5. Xiong $Y$, Liu Y, Cao L, Wang D, Guo $M$, Jiang $A$, et al. Transcriptomic characteristics of bronchoalveolar lavage fluid and peripheral blood mononuclear cells in COVID-19 patients. Em Micro Infect 2020;9:761-70.

6. Ohnishi H, Yokoyama A, Kondo K, Hamada $H$, Abe M, Nishimura $K$, et al. Comparative study of KL-6, surfactant protein- $A$, surfactant protein- $D$, and monocyte chemoattractant protein-1 as serum markers for interstitial lung diseases. Am J Respir Crit Care 2002;165:378-81.

7. Li G, Siddiqui J, Hendry M, Akiyama J, Edmondson I, Brown $C$, et al. Surfactant protein-A-deficient mice display an exaggerated early inflammatory response to a $\beta$-resistant strain of influenza A virus. Am J Respir Cell Mol Bio 2002;26:277-82.

8. Yuen K-S, Ye Z-W, Fung S-Y, Chan C-P, Jin D-Y. SARS-CoV-2 and COVID-19: The most important research questions. Cell Bio 2020;10:1-5.

9. Zhao M. Cytokine storm and immunomodulatory therapy in COVID-19: role of chloroquine and anti-IL-6 monoclonal antibodies. Int I Antimicrob Agents 2020;55:1-3.

10. Cao YC, Deng QX, Dai SX. Remdesivir for severe acute respiratory syndrome coronavirus 2 causing COVID-19: An evaluation of the evidence. Travel Med Infect Dis 2020;35:1-6.
11. Channappanavar R, Perlman S, editors. Pathogenic human coronavirus infections: causes and consequences of cytokine storm and immunopathology. Semin Immunopathol; 2017;39:529-39.

12. Russell B, Moss C, George G, Santaolalla A, Cope A, Papa $S$, et al. Associations between immune-suppressive and stimulating drugs and novel COVID-19-a systematic review of current evidence. Ecancer 2020;14:1022.

13. Henderson LA, Canna SW, Schulert GS, Volpi S, Lee PY, Kernan $K F$, et al. On the alert for cytokine storm: Immunopathology in COVID-19. Arthritis Rheum 2020;72:1059-63.

14. McGonagle D, Sharif $K, O^{\prime}$ Regan A, Bridgewood C. Interleukin-6 use in COVID-19 pneumonia related macrophage activation syndrome. Autoimmun Rev 2020;19:1-7.

15. Ye Q, Wang B, Mao J. The pathogenesis and treatment of theCytokine Storm'in COVID-19. I Infect 2020;80:607-13.

16. Ackermann $M$, Verleden SE, Kuehnel $M$, Haverich $A$, Welte $T$, Laenger $F$, et al. Pulmonary vascular endothelialitis, thrombosis, and angiogenesis in COVID-19. New Engl J Med 2020;383:120-8.

17. Liu B, Li M, Zhou Z, Guan X, Xiang Y. Can we use interleukin-6 (IL-6) blockade for coronavirus disease 2019 (COVID-19)-induced cytokine release syndrome (CRS)? J Autoimmun 2020;111;1-8.

18. Greene $K$, Ye S, Mason R, Parsons P. Serum surfactant protein-A levels predict development of ARDS in at-risk patients. Chest 1999;116:90-1.

19. Ballard PL, Nogee LM, Beers MF, Ballard RA, Planer BC, Polk $L$, et al. Partial deficiency of surfactant protein $B$ in an infant with chronic lung disease. Pediatrics 1995;96:1046-52.

20. Mason RJ, Greene K, Voelker DR. Surfactant protein A and surfactant protein $D$ in health and disease. Am I Physiol Lung Cell Mol Physio 1998;275:1-13.

21. Hartshorn KL. Role of surfactant protein A and D (SP-A and $S P-D)$ in human antiviral host defense. Front Biosci 2010;2:527-46.

\author{
Yazıșma Adresi/Address for Correspondence \\ Dr. Ferhan KERGET \\ Erzurum Bölge Eğitim Araștırma Hastanesi, \\ İnfeksiyon Hastalıkları ve \\ Klinik Mikrobiyoloji Anabilim Dalı, \\ Erzurum-Türkiye \\ E-posta: drferhan68@hotmail.com
}

